\title{
Steroid-protein interactions in bovine plasma
}

\author{
B. Martin, C. Fouchet and M. Thibier* \\ Laboratoire de Physiologie de la Reproduction (groupe Stéroïdes), Université P. \& M. Curie, \\ 12 Rue Cuvier, 75005 Paris, and ${ }^{*}$ Laboratoire de la chaire de Zootechnie, Centre de Grignon, \\ Institut National Agronomique Paris-Grignon, 78850 Thiverval-Grignon, France
}

\begin{abstract}
Summary. The binding of testosterone, corticosterone and 17a-hydroxyprogesterone by bull plasma protein was studied by equilibrium dialysis. Testosterone in bovine plasma was bound by a CBG-like protein and by a specific protein (testosteronebinding protein or TBP) of limited capacity and high affinity. The TBP was specific for $C_{18}$ and $C_{19}$ steroids with a $17 \beta$-hydroxy group. Precision of the steroid-protein binding measurements was tested and was satisfactory. The testosterone-binding capacity in bull plasma samples did not seem to be related to testosterone levels in peripheral plasma. Significant differences between bulls and cows with regard to the binding capacity were observed.
\end{abstract}

\section{Introduction}

Testosterone is the most important androgen secreted by the testicular interstitial tissue of the adult bull (Lindner, 1969). A peripheral plasma concentration of about $4.5 \mathrm{ng} / \mathrm{ml}$ may be reached by 9 months of age (Thibier, 1975a). The available evidence indicates that the biosynthesis of testosterone occurs via the $\Delta^{4}$ pathway: progesterone $\rightarrow 17 \alpha$-hydroxyprogesterone $\rightarrow$ androstenedione $\rightarrow$ testosterone.

Many steroid hormones are strongly bound to plasma proteins in the blood (Westphal, 1971). In man, two kinds of proteins are known to bind steroids with high affinity and limited capacity: (1) corticosteroid-binding globulin, CBG (Daughaday, 1956, 1958a), or transcortin, which specifically binds $C_{21}$ steroids, and (2) sex steroid-binding protein, SBP (Daughaday, 1958b; Mercier, Alfsen \& Baulieu, 1966; Mercier-Bodard, Alfsen \& Baulieu, 1970), which specifically binds $C_{18}$ and $C_{19}$ sex steroids. Other components, such as orosomucoid and albumin, are able to bind steroids in man (Sandberg, Slaunwhite \& Antoniades, 1957; Westphal, Ashley \& Selden, 1961; Westphal, 1964, 1971), but they possess a much lower affinity for steroids than do CBG and SBP. Little has been published on the steroid-binding proteins in bovine plasma. The presence of a "corticosteronebinding globulin"-like protein which specifically binds cortisol and corticosterone was reported by Lindner (1964) and Seal \& Doe (1965), and a high-affinity binding for testosterone has been shown to occur in bovine plasma (Murphy, 1968). Direct evidence for a testosterone-binding protein (TBP) came from polyacrylamide gel electrophoresis which resulted in the separation from both albumin and CBG of a TBP (Corvol \& Bardin, 1973). From the amount of testosterone associated during serum fractionation by electrophoresis, the binding affinity was classified as 'moderate' by these authors.

The purpose of the present investigation was: (1) to analyse the testosterone-binding specificity in bull plasma, (2) to determine the concentrations and dissociation constants of the various steroids found in bovine plasma, and (3) to study the testosterone-binding activity in bulls in different physiological states.

\section{Animals}

\section{Materials and Methods}

A blood sample was taken from each of sixteen French Friesian bulls at $52 \pm 0.5$ weeks of age by puncture of the jugular vein. The bulls were individually penned in a performance test station and 
had all been maintained under similar conditions since they were 8 days old. Their mean ( \pm S.D.) weight at 1 year of age was $434 \pm 44 \mathrm{~kg}$. After 9 months of age they were trained to ejaculate into an artificial vagina once a week. Libido and sperm production were normal. Plasma obtained from the blood samples was allocated to one of two groups according to the testosterone concentrations. The eight bulls in Group I had a testosterone concentration $<2 \mathrm{ng} / \mathrm{ml}$ (mean $=1 \cdot 19 \mathrm{ng} / \mathrm{ml}$ ), and those in Group II had testosterone concentrations $>5 \mathrm{ng} / \mathrm{ml}$ (mean $=7.47 \mathrm{ng} / \mathrm{ml}$ ). Blood samples were also taken from the jugular vein of six French Friesian cows 21 days after artificial insemination. Three of the cows were pregnant and the peripheral plasma progesterone levels in the other three were $<0.5 \mathrm{ng} / \mathrm{ml}$, suggesting that they were in the follicular phase (Thibier \& Saumande, 1974). The blood was centrifuged immediately after sampling $(2800 \mathrm{~g}$ for $10 \mathrm{~min})$ and plasma was decanted and stored at $-20^{\circ} \mathrm{C}$ until assayed.

\section{The steroid-protein binding measurement}

The radioinert (Roussel-Uclaf) and labelled (N.E.N.) steroids used were: $\left[1,2,6,7 .{ }^{3} \mathrm{H}\right]$ testosterone $(81 \mathrm{Ci} / \mathrm{mmol}),\left[1,2-{ }^{3} \mathrm{H}\right] 17 \alpha$-hydroxyprogesterone $(50 \cdot 3 \mathrm{Ci} / \mathrm{mmol}),\left[1,2-{ }^{3} \mathrm{H}\right]$ corticosterone $(50 \mathrm{Ci} / \mathrm{mmol})$. Steroids were shown to be homogeneous by thin-layer chromatography. A $0 \cdot 01 \mathrm{M}-$

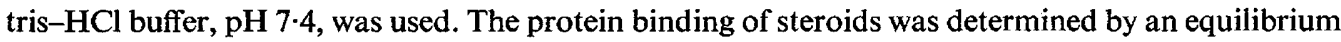
dialysis method. Dialysis tubing was washed with distilled water and tris- $\mathrm{HCl}$ buffer. For all experiments, $1 \mathrm{ml}$ diluted whole serum $(1 / 20,1 / 40$, and $1 / 80)$ was placed inside the bag and the radioactive steroid was placed outside the bag in $4 \mathrm{ml}$ tris- $\mathrm{HCl}$ buffer. In competitive experiments the unlabelled steroid was placed with the labelled steroid outside the bag. To each dialysing system were added various amounts of non-radioactive steroid ranging from $10^{-10}$ to $10^{-7} \mathrm{M}$ and a fixed amount $\left(1 \times 10^{-10} \mathrm{M}\right)$ of labelled steroid. All binding experiments were performed at $4^{\circ} \mathrm{C}$ with stirring, for a set time of $48 \mathrm{hr}$. In some experiments, in order to remove most of the endogenous steroids, plasma was subjected to charcoal (Norit A) treatment (Heyns, van Baelen \& de Moor, 1967). The percentage of steroid binding was determined by the following equation: \% bound $=100\left[1-\left(D . V_{\mathrm{r}}\right) /\left(R . V_{\mathrm{d}}\right)\right]$, where $R$ and $D$ are the total amounts of radioactivity present inside and outside the dialysis bag, respectively, and $V_{\mathrm{r}}$ and $V_{\mathrm{d}}$ are the corresponding volumes (Sandberg, Rosenthal, Schneider \& Slaunwhite, 1966). Steroid binding constants, binding capacity $(N)$ and constant of dissociation $\left(K_{\mathrm{D}}\right)$ were determined from results obtained by the equilibrium dialysis binding experiments, in which a fixed quantity of labelled steroid and various amounts of the unlabelled steroids were used. Estimation and statistical evaluation of binding parameters were analysed on the assumption that each binding system was independent, the sites of each system were identical, there was no cooperative effect, the system obeyed the law of mass action, and proteins did not affect the activity of steroids except by binding. These binding constants were calculated (1) by a computational method (C II 10070 computer; Raynaud, 1973) and (2) by a graphic analysis according to Scatchard (1949) as modified by Rosenthal (1967). Similar results were obtained by both methods.

\section{Steroid assays}

Testosterone and progesterone were measured by radioimmunoassay with antisera raised in rabbits. The procedures were very similar for the two steroid assays and the reliability of the method was satisfactory (Thibier, Castanier, Tea \& Scholler, 1973; Leymarie, Roger, Castanier \& Scholler, 1974; Thibier, 1975a). Inter-assay precision for duplicate assays was $7 \cdot 3 \%$ for testosterone and $11 \%$ for $17 \alpha$-hydroxyprogesterone and progesterone. The limits of sensitivity for the assays of these three steroids calculated as described by Currie $(1968)$ were $0.03,0.05$ and $0.07 \mathrm{ng} / \mathrm{ml}$, respectively.

\section{Steroid-protein interactions}

\section{Results}

Binding constants. Bull plasma bound testosterone, corticosterone and $17 \alpha$-hydroxyprogesterone with high affinity and limited capacity. The mean \pm S.D. binding capacities $(N)$ and dissociation 
constants $\left(K_{\mathrm{D}}\right) \times 10^{-9} \mathrm{M}$ were: testosterone, $N=204 \cdot 0 \pm 20 \cdot 8$ (see Text-fig. 1 ), $K_{\mathrm{D}}=2 \cdot 71 \pm 0 \cdot 28$; corticosterone, $N=85 \cdot 8 \pm 5 \cdot 2, K_{\mathrm{D}}=2 \cdot 43 \pm 0 \cdot 14 ; 17 \alpha$-hydroxyprogesterone, $N=34 \cdot 6 \pm 9 \cdot 8, K_{\mathrm{D}}=1 \cdot 86 \pm 0 \cdot 54$. The fact that the binding capacity for testosterone is 2.5 times greater than that for corticosterone suggests the existence of two binding proteins for testosterone. When bull plasma was saturated with a high concentration of corticosterone $\left(3 \times 10^{-4} \mathrm{M}\right)$ for $48 \mathrm{hr}$, the binding capacity for testosterone was $114 \pm 19 \cdot 8 \times 10^{-9} \mathrm{M}$, and this binding system was considered to be the TBP.

Accuracy of the binding constant values. This was estimated by the coefficient of variation of results obtained by repeated determinations $(n=12)$ of $K_{\mathrm{D}}$ and $N$ from the same plasma samples. The mean values of $K_{\mathrm{D}}$ and $N$ in these series were not significantly different. The mean precision and

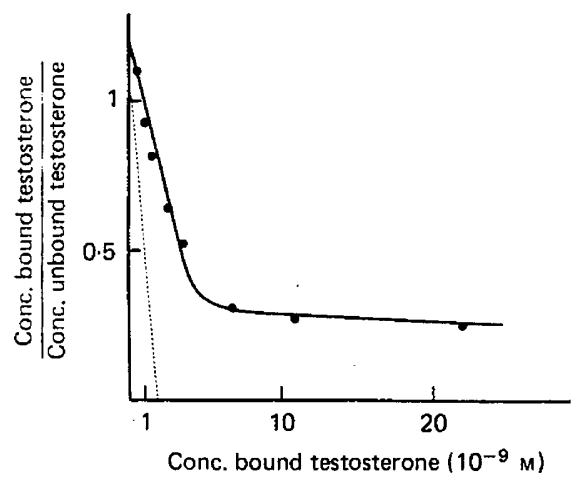

Text-fig. 1. Binding of testosterone $(-)$ to bull plasma as determined by equilibrium dialysis experiments with plasma diluted $1 / 80$. The broken line represents the Scatchard-type plot as modified by Rosenthal (1967).
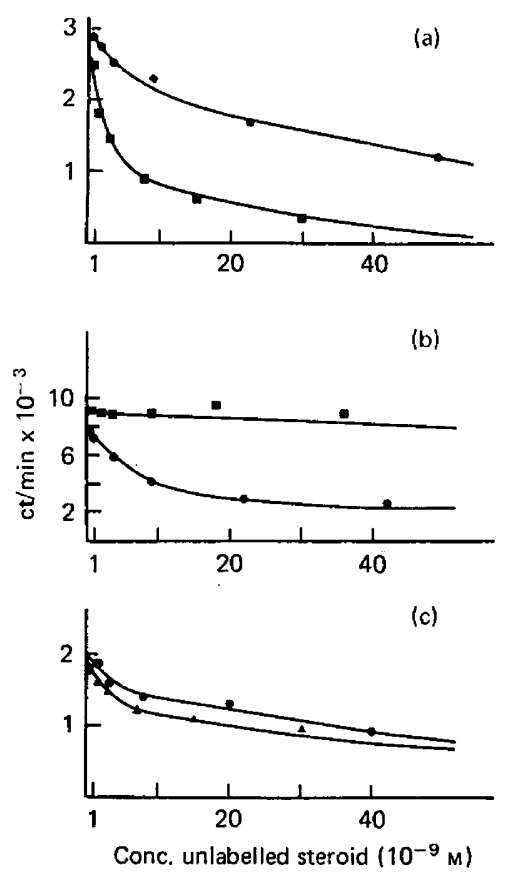

Text-fig. 2. Competition for the bound $\left[{ }^{3} \mathrm{H}\right]$ corticosterone (a), $\left[{ }^{3} \mathrm{H}\right]$ testosterone (b) and $\left[{ }^{3} \mathrm{H}\right] 17 \alpha$-hydroxyprogesterone (c) in bull plasma diluted $1 / 20$ as a function of the unlabelled steroid concentration. Competitive steroids were $17 \alpha$-hydroxyprogesterone $(\Delta)$, testosterone $(\bullet)$ and corticosterone $(\square)$. 
confidence limits $(P<0.05)$ was $2.32 \times 10^{-9} \mathrm{M}\left(1 \cdot 80<K_{\mathrm{D}}<2 \cdot 84\right)$ and $166.4 \times 10^{-9} \mathrm{M}(134.9<N<197 \cdot 8)$ for the inter-assay determinations and $2.11 \times 10^{-9} \mathrm{M}\left(1.80<K_{\mathrm{D}}<2.42\right)$ and $172.8 \times 10^{-9} \mathrm{M}(152.5<N<$ 193.1) for the intra-assay determination.

Specificity studies. Competition experiments were performed between testosterone, corticosterone and 17 $\alpha$-hydroxyprogesterone by increasing the amount of unlabelled steroids (Text-fig. 2). The competition of testosterone and $\left[{ }^{3} \mathrm{H}\right]$ testosterone, and corticosterone and $\left[{ }^{3} \mathrm{H}\right]$ corticosterone were used as controls. Testosterone was able to compete with $\left[{ }^{3} \mathrm{H}\right]$ corticosterone, although corticosterone was a weak inhibitor of $\left[{ }^{3} \mathrm{H}\right]$ testosterone-binding proteins, and with $\left[{ }^{3} \mathrm{H}\right] 17 \alpha$-hydroxyprogesterone. The results of competition experiments with several steroids against the $\left[{ }^{3} \mathrm{H}\right]$ testosterone binding by bull plasma diluted $1 / 80$ are shown in Table 1 . The steroids could be assigned to one of three groups according to their specificity. The ability to displace $\left[{ }^{3} \mathrm{H}\right]$ testosterone from the high-affinity binding sites was a property of four $\mathrm{C}_{19}$ steroids (Group 1). Less displacement by the seven steroids of Group 2 was observed. The remaining steroids (Group 3) competed either poorly or not at all. The competitive binding ability of several steroids against $\left[{ }^{3} \mathrm{H}\right]$ testosteronebinding protein was further studied with bull plasma which had been saturated with corticosterone $\left(3 \times 10^{-4} \mathrm{M}\right)$. From the results in Table 2, it appears that $5 \alpha$-androstan-17 $\beta$-ol,3-one competed more strongly than testosterone and $5 \alpha$-androstan-3 $3,17 \beta$-diol was also a good competitor whereas oestradiol-17 $\beta$ and $5 \alpha$-androstan-3 $\alpha, 17 \beta$-diol were poor competitors. Deoxycorticosterone, $17 \alpha$ hydroxyprogesterone and progesterone did not exhibit any competitive effect.

Table 1. Testosterone-binding specificity in bull plasma diluted $1 / 80$

\begin{tabular}{|c|c|}
\hline Unlabelled steroids & $\begin{array}{c}{\left[{ }^{3} \mathrm{H}\right] \text { testosterone }} \\
\text { bound }(\%)\end{array}$ \\
\hline 一 & $54 \cdot 3 \pm 1 \cdot 53$ \\
\hline \multicolumn{2}{|l|}{ Group 1} \\
\hline $5 \alpha$-Androstan-17 $\beta$-ol,3-one & $21 \cdot 3 \pm 1 \cdot 52$ \\
\hline Testosterone & $21.6 \pm 0.57$ \\
\hline $5 \alpha$-Androstan-3 $\alpha, 17 \beta$-diol & $22 \cdot 6 \pm 3 \cdot 51$ \\
\hline $5 \alpha$-Androstan-3$\beta, 17 \beta$-diol & $24 \cdot 0 \pm 1 \cdot 73$ \\
\hline \multicolumn{2}{|l|}{ Group 2} \\
\hline Deoxycorticosterone & $32 \cdot 3 \pm 1 \cdot 51$ \\
\hline Oestradiol-17 $\beta$ & $32 \cdot 3 \pm 1 \cdot 53$ \\
\hline Progesterone & $35 \cdot 6 \pm 2 \cdot 3$ \\
\hline $17 \alpha$-Hydroxyprogesterone & $36.0 \pm 1.73$ \\
\hline Dehydroepiandrosterone & $36 \cdot 0 \pm 1 \cdot 0$ \\
\hline Androstenedione & $38 \cdot 0 \pm 3 \cdot 6$ \\
\hline Epiandrosterone & $38 \cdot 0 \pm 1 \cdot 0$ \\
\hline \multicolumn{2}{|l|}{ Group 3} \\
\hline Testosterone-17 $\alpha$ & $42 \cdot 0 \pm 3 \cdot 0$ \\
\hline Oestradiol-17 $\alpha$ & $43.3 \pm 2.08$ \\
\hline Oestrone & $46 \cdot 0 \pm 2 \cdot 0$ \\
\hline $5 \beta$-Androstan-3a,17 $\beta$-dio & $47 \cdot 6 \pm 0.57$ \\
\hline Cortisone & $49 \cdot 0 \pm 1 \cdot 0$ \\
\hline Corticosterone & $49 \cdot 6 \pm 4 \cdot 04$ \\
\hline Cortisol & $52 \cdot 3 \pm 3 \cdot 20$ \\
\hline $5 \beta$-Androstanedione & $52.7 \pm 3.05$ \\
\hline Etiocholanolone & $56 \cdot 6 \pm 1.52$ \\
\hline
\end{tabular}

Competition studies by equilibrium dialysis with unlabelled steroid $\left(1 \times 10^{-7} \mathrm{M}\right)$ added to the plasma with $1.7 \times 10^{-10} \mathrm{M}-\left[{ }^{3} \mathrm{H}\right]$ testosterone. Values are means \pm S.D. for three measurements.

\section{Influence of peripheral plasma testosterone concentration on TBP activity}

The testosterone concentrations and binding constant values for bull plasma are shown in Table 3. The coefficients of variation of $K_{\mathrm{D}}$ and $N$ were around $30 \%$. Comparison of mean binding constant 
Table 2. Competition studies with various steroids in bull plasma diluted 1/40 and saturated with corticosterone $\left(3 \times 10^{-4} \mathrm{M}\right)$

\begin{tabular}{lrrr}
\hline & \multicolumn{3}{c}{$\begin{array}{c}\text { Unlabelled steroid } \\
\text { concentration }\end{array}$} \\
\cline { 2 - 4 } & $1 \mathrm{nM}$ & $10 \mathrm{nM}$ & $100 \mathrm{nM}$ \\
\hline Testosterone & - & 21 & 34 \\
$5 \alpha$-Androstan-17 $\beta$-ol,3-one & 10 & 32 & 38 \\
$5 \alpha$-Androstan-3 $\beta, 17 \beta$-diol & 4 & 17 & 32 \\
Oestradiol-17 $\beta$ & 1 & 8 & 26 \\
$5 \alpha$-Androstan-3 $\alpha, 17 \beta$-diol & 2 & 4 & 18 \\
Deoxycorticosterone & 0 & 4 & 15 \\
$17 \alpha$-Hydroxyprogesterone & 1 & 3 & 13 \\
Progesterone & 0 & 3 & 7 \\
\hline
\end{tabular}

The unlabelled steroid was added to the plasma with $1 \mathrm{~nm}-\left[{ }^{3} \mathrm{H}\right]$ testosterone and the figures indicate the percentage decrease in the bound radioactive testosterone.

values of Group I and II bulls showed no significant differences for $N$, but a significant one for $K_{\mathrm{D}}$. The plasma samples from Group II bulls had a higher $K_{\mathrm{D}}$. Intra-group correlation between either $K_{\mathrm{D}}$ or $N$ and testosterone level was not significant $(P>0.05)$. The binding constant values for TBP were similar in pregnant and non-pregnant cows (Table 3), and the coefficients of variation were again around $30 \%$. The mean $K_{\mathrm{D}}$ values in cows were intermediate between those of the bulls in Groups I and II $(P>0.05)$. The $N$ constant values of cows were significantly higher $(P<0.05)$ than those of bulls. For all animals, the $N$ and $K_{\mathrm{D}}$ correlations were highly significant $(P<0.01)$.

Table 3. The mean ( \pm S.D.) testosterone-binding capacities $(N)$ and dissociation constants $\left(K_{\mathrm{D}}\right)$ in the plasma of bulls and cows, and plasma testosterone concentrations in bulls (not detectable in cows)

\begin{tabular}{llll}
\hline & $N \times 10^{-9} \mathrm{M}$ & $K_{\mathrm{D}} \times 10^{-9} \mathrm{M}$ & Testosterone (ng/ml) \\
\hline Bulls & & & \\
$\quad$ Group I + Group II (16) & $202 \pm 54 \cdot 1^{*}$ & $2.88 \pm 0.92$ & $4.33 \pm 3.99$ \\
$\quad$ Group I (8) & $182 \pm 51.2$ & $2.38 \pm 0.32 \dagger$ & $1.19 \pm 0.50$ \\
$\quad$ Group II (8) & $221 \pm 52.7$ & $3.37 \pm 1.07 \dagger$ & $7.47 \pm 1.38$ \\
Cows & & & \\
Pregnant + non-pregnant (6) & $282 \pm 75.0^{*}$ & $2.68 \pm 0.63$ & \\
Pregnant (3) & $286 \pm 95.9$ & $2.73 \pm 0.41$ & \\
$\quad$ Non-pregnant (3) & $279 \pm 69.8$ & $2.62 \pm 0.91$ & \\
\hline
\end{tabular}

* Significant, $P<0.05$ (Student's $t$ test).

$\uparrow$ Significant, $P<0.05$ (Student's $t$ test).

\section{Discussion}

The presence of two specific proteins binding testosterone with high affinity and limited capacity has been confirmed in bull plasma. Displacement studies, as well as the binding capacities determined for corticosterone and testosterone in whole plasma and in whole plasma saturated with corticosterone, show that CBG and TBP molecules are both involved in the binding of testosterone. The competition experiments suggest that a $17 \beta$-hydroxy group in a $C_{19}$ steroid structure (with $\Delta^{4}$ or $5 \alpha, 3$ keto or $3 \alpha-$ or $3 \beta$-hydroxy) is necessary for interaction with the TBP. When the binding of testosterone with testosterone-17 $\alpha$ or with androstenedione is compared, it is seen that the 17 $\alpha$ hydroxy group and the 17-keto group cause a large decrease in binding activity. The 5a-reduced 
$17 \beta$-hydroxy metabolites of testosterone, such as $5 \alpha$-androstan-17 $\beta$-ol,3-one and $5 \alpha$-androstan$3 \beta, 17 \beta$-diol, are bound to an extent similar to that of testosterone. The binding is lowered by the presence of a $5 \beta$ structure as indicated by comparing $5 \alpha$-androstan- $3 \alpha, 17 \beta$-diol with $5 \beta$-androstan$3 \alpha, 17 \beta$-diol. As far as the various $C_{19}$ steroids are concerned, TBP seems to bind them with the same affinity as does SBP in man (Kato \& Horton, 1968; Vermeulen \& Verdonck, 1968; Mercier-Bodard et al., 1970). For $C_{18}$ steroids, oestradiol-17 $\beta$ is bound to the TBP with a lower affinity than the $\mathrm{C}_{19}$ steroids and competes with the testosterone-TBP complex more strongly than do oestradiol- $17 \alpha$ and oestrone.

The precision of the steroid-protein binding measurement was considered satisfactory. The coefficient of variation of the site concentration was about $20 \%$ for the intra-assay precision and the reliability of this procedure therefore renders it useful for studies of physiological conditions. The mean testosterone concentration found in the bulls in the present study was very similar to that of randomly sampled bulls of that age (Thibier, 1975a). It is therefore reasonable to assume that the mean binding constants of 1-year-old bulls would be about $200 \times 10^{-9} \mathrm{M}$ for $N$ and $3 \times 10^{-9} \mathrm{M}$ for $K_{\mathrm{D}}$. The testosterone-binding capacity $(N)$ does not seem to be related to testosterone levels, but binding affinity was significantly higher in plasma samples with low levels of testosterone. As $K_{\mathrm{D}}$ and $N$ are quite closely related, this may appear rather illogical and the reason for this discrepancy is unknown. It has been shown by Katongole, Naftolin \& Short (1971) and Thibier (1975b) that peripheral plasma testosterone levels in bulls fluctuate during the day. Since only one sample was taken from each bull, it was not known whether daily testosterone patterns of the bulls in Groups I and II were significantly different (Thibier, 1975b). Comparison of the binding constants for the bulls and cows seems to be more useful in this respect. The mean values of testosterone-binding capacity appeared to be significantly different in males and females. This suggests that plasma samples with very low levels of testosterone have a higher mean value of $N$. In our study, $N$ was $40 \%$ higher in cows than in bulls and testosterone levels in the females were below $0.05 \mathrm{ng} / \mathrm{ml}$, i.e. less than $\frac{1}{50}$ those in the young bulls. It may be concluded from the differences between $N$ in males and females that increased plasma testosterone concentration reduces the TBP activity. Similar results have been reported for human serum by Dray (1969) and de Moor, Steeno, Heyns \& van Balaen (1969). After puberty in humans, values for males are significantly lower than those for females, but in females with hirsutism 'male' values are observed and in males with hypogonadism 'female' values are found (Vermeulen, Verdonck, van der Straeten \& Orie, 1969). It is interesting to correlate these findings with the observations that testosterone also decreases the levels of other plasma proteins such as transcortin in the rat (Gala \& Westphal, 1965).

In cows, there was no significant difference in the values of the constants between early pregnant and non-pregnant females. Several authors (Shemesh, Ayalon \& Lindner, 1968; Stabenfeldt et al., 1969, 1970; Edqvist, Ekman, Gustaffson \& Astrom, 1970; Donaldson, Bassett \& Thorburn, 1970) have shown that progesterone levels in the cow are much higher in pregnancy than in the follicular phase. Progesterone levels seem therefore to have no influence on the binding constants of TBP.

This work was partly supported by the Union Nationale des Coopératives d'Elevage et d'Insémination Artificielle, the Délégation Générale à la Recherche Scientifique et Technique and the Centre Nationale de la Recherche Scientifique. The authors gratefully acknowledge R. Bellé for his help with the computer programming and $\mathbf{N}$. Jeanguyot for her skilful assistance.

\section{References}

Corvol, P. \& Bardin, C.W. (1973) Species distribution of testosterone-binding globulin. Biol. Reprod. 8, 277-282.

Currie, L.A. (1968) Limits for qualitative detection and quantitative determination. Application to radiochemistry. Analyt. Chem. 40, 586-593.

DaughadaY, W.H. (1956) Evidence for two corticosteroid binding systems in human plasma. J. Lab. clin. Med. 48, 799-808.
DAUGHADAY, W.H. (1958a) Binding of corticosteroids by plasma proteins. IV. The electrophoretic demonstration of corticosteroid-binding globulin. J. clin. Invest. 37, 519-523.

Daughaday, W.H. (1958b) Binding of corticosteroids by plasma proteins. III. The binding of corticosteroid and related hormones by human plasma and plasma protein fractions as measured by equilibrium dialysis. J. clin. Invest. 37, 511-518. 
de Moor, P., Steeno, O., Heyns, W. \& van Baelen, $H$. (1969) The steroid binding $\beta$-globulin in plasma: pathophysiological data. Annls Endocr. 30, 233-239.

Donaldson, L.E., Bassetr, J.M. \& Thorburn, G.D. (1970) Peripheral plasma progesterone concentration of cows during puberty, oestrous cycles, pregnancy and lactation and the effects of undernutrition or exogenous oxytocin on progesterone concentration. J. Endocr. 48, 599-614.

Dray, F. (1969) Physiologie de la liaison de la testostérone, de l'oestradiol et du cortisol avec les protéines sériques. Rapports de la $\mathrm{X}^{\mathrm{e}}$ Réunion des Endocrinologistes de Langue Française, Paris, pp. 159-180.

Edquist, L.E., Ekman, L., Gustafsson, B. \& Astrom, G. (1970) Progesterone levels in the bovine peripheral plasma measured by the competitive protein binding technique. Zentbl. VetMed. A 17, 899-908.

Gala, R.R. \& WestPhal, U. (1965) Corticosteroidbinding globulin in the rat: studies on the sex difference. Endocrinology 77, 841-851.

Heyns, W., van Baelen, H. \& de Moor, P. (1967) Study of steroid-protein binding by means of competitive adsorption: application to cortisol binding in plasma. Clin. chim. Acta 18, 361-370

Kato, T. \& HorTON, R. (1968) Studies of testosteronebinding globulin. J. clin. Endocr. Metab. 28, 1160 1168.

Katongole, C.B., Naftolin, F. \& Short, R.V. (1971) Relationship between blood levels of luteinizing hormone and testosterone in bulls, and the effects of sexual stimulation. J. Endocr. 50, 457-466.

Leymarie, P., Roger, M., Castanier, M. \& Scholler, R. (1974) Circadian variations of plasma testosterone and estrogens in normal men. A study by frequent sampling. J. Steroid Biochem. 5, 167-171.

LINDNER, H.R. (1964) Comparative aspects of cortisol transport: lack of firm binding to plasma proteins in domestic ruminants. $J$. Endocr. 28, 301-312.

LINDNER, H.R. (1969) The androgenic secretion of the testis in domestic ungulates. In The Gonads, pp. 615648. Ed. K. W. McKerns. North Holland Publishing, Amsterdam.

Mercier, C., Alfsen, A. \& Baulieu, E.E. (1966) A testosterone binding globulin. Proc. 2nd Int. Symp. Steroid Hormones, Ghent, p. 212. Excerpta Med. Int Congr. Ser. No. 101.

Mercier-Bodard, C., Alfsen, A. \& Baulieu, E.E. (1970) Sex steroid binding plasma protein (SBP). Acta endocr., Copenh., Suppl. 147, 204-224.

MurPhy, B.E.P. (1968) Binding of testosterone and estradiol in plasma. Can. J. Biochem. 46, 299-302.

RAYNAUD, J.P. (1973) A computer program for the analysis of binding experiments. Computer Programs in Biomedicine 3, 63-78.

Rosenthal, H.E. (1967) A graphic method for the determination and presentation of binding parameters in a complex system. Analyt. Biochem. 20, 525-532.

Sandberg, A.A., Slaunwhite, W.R., JR \& Antoniades,
H.N. (1957) The binding of steroids and steroid conjugates to human plasma proteins. Recent Prog. Horm. Res. 13, 209-267.

Sandberg, A.A., Rosenthal, H., Schneider, S.L. \& Slaunwhite, W.R., JR (1966) Protein-steroid interactions and their role in the transport and metabolism of steroids. In Steroid Dynamics, pp. 1-61. Eds G. Pincus, T. Nakao \& J. F. Tait. Academic Press, New York.

SCATChaRd, G. (1949) The attractions of proteins for small molecules and ions. Ann. N.Y. Acad. Sci. 51, 660-672.

SEAL, U.S. \& DoE, R.P. (1965) Vertebrate distribution of corticosteroid-binding globulin and some endocrine effects on concentration. Steroids 5, 827-841.

Shemesh, M., Ayalon, N. \& Lindner, H.R. (1968) Early effect of conceptus on plasma progesterone level in the cow. J. Reprod. Fert. 15, 161-164.

Stabenfeldt, G.H., Osburn, B.I. \& Macdonald, L.E. (1969) Peripheral plasma progesterone levels during the bovine oestrous cycle. J. Reprod. Fert. 19, $433-442$.

Stabenfeldt, G.H., Osburn, B.I. \& Ewing, L.L. (1970) Peripheral plasma progesterone levels in the cow during pregnancy and parturition. $A m . J$. Physiol. 218, 571-575.

ThIBIER, M. (1975a) Peripheral plasma testosterone concentrations in bull around puberty. J. Reprod. Fert. 42, 567-569.

Thibier, M. (1975b) Diurnal testosterone and 17hydroxyprogesterone levels in peripheral plasma of young post-pubertal bulls. A study by frequent sampling. Acta endocr., Copenh. (in press).

Thibier, M. \& SAUMANDE, J. (1974) Concentrations plasmatiques de la 17-hydroxyprogestérone et de la progestérone au cours de la phase folliculaire de la vache. Etude par prélèvements fréquents. $C$. $r$. Séanc. Soc. Biol. 168, 1186-1190.

Thibier, M., Castanier, M., Tea, N.T. \& Scholler, R. (1973) Concentrations plasmatiques de la 17 hydroxyprogestérone au cours du cycle de la vache. C. r. hebd. Séanc. Acad. Sci., Paris 276, 3049-3052.

Vermeulen, A. \& VerdonCK, L. (1968) Studies on the binding of testosterone to human plasma. Steroids 11, 609-635.

Vermeulen, A., Verdonck, L., VAn der Straeten, M. \& ORIE, N. (1969) Capacity of the testosteronebinding globulin in human plasma and influence of specific binding of testosterone on its metabolic clearance rate. J. clin. Endocr. Metab. 29, 1470-1480.

WestPHAL, U. (1964) Binding of steroids to proteins. J. Am. Oil Chem. Soc. 41, 481-490.

WestPhal, U. (1971) Steroid-Protein Interactions. (Monographs on Endocrinology, IV.) SpringerVerlag, Berlin.

Westphal, U., Ashley, B.D. \& Selden, G.L. (1961) Steroid-protein interactions. VII. Interactions of progesterone and corticosteroids with human plasma proteins determined by multiple equilibrium dialysis. Archs Biochem. 92, 441-448. 